Article

\title{
A Methodological Proposal for Corporate Carbon Footprint and Its Application to a Wine-Producing Company in Galicia, Spain
}

\author{
Adolfo Carballo Penela ${ }^{1, *}$, María do Carme García-Negro ${ }^{1}$ and Juan Luís Doménech Quesada ${ }^{2}$ \\ 1 Fisheries Economics and Natural Resources Research Group-USC, Facultade de CC Económicas e \\ Empresariais, Av. Burgo de las Nacións s/n, Santiago de Compostela, CP. 15782, A Coruña- \\ Galicia, Spain; E-mail: maricarme.garcia.negro@usc.es \\ 2 Port of Gijón, c/Claudio Alvargonzález, 32; 33290 Gijón, Asturias, Spain; \\ E-Mail: jdomenech@puertogijón.es
}

* Author to whom correspondence should be addressed; E-Mail: adolfo.carballo@usc.es;

Tel.: +34-981-563100 Ext. 11649; Fax: +34-981-547036

Received: 22 April 2009 / Accepted: 11 June 2009 / Published: 16 June 2009

\begin{abstract}
Corporate carbon footprint (CCFP) is one of the most widely used indicators to synthesise environmental impacts on a corporate scale. We present a methodological proposal for CCFP calculation on the basis of the "method composed of financial accounts" abbreviated as MC3, considering the Spanish version "metodo compuesto de las cuentas contables". The main objective is to describe how this method and the main outputs obtained work. This latter task is fulfilled with a practical case study, where we estimate the carbon footprint of a wine-producing company for the year 2006. Results show the origin of impacts generated, providing this firm with disaggregated information on the contribution to its CCFP of each one of its activities and consumptions.
\end{abstract}

Keywords: ecological footprint analysis; carbon corporate footprint; MC3

\section{Introduction: Corporate Sustainability and Ecological Footprint Analysis}

Over the last few decades, organisations have gained better awareness on issues that have traditionally played a secondary role or were simply not regarded as business strategies. This is particularly true in the case of environmental sustainability-related questions. 
From a business perspective, more value is now placed on these matters, particularly in light of: i) the development of legislation related to emissions and waste discharge control levels; ii) informational tasks regarding environment-related issues; iii) the demand for higher transparency and commitment by related agents; iv) an awareness that the relation with several collectives (shareholders, clients, workers, community, etc.) and the environment is integrated with the firm's value; or v) the search for new tools to manage profits and risks derived from intensifying globalisation processes and the disappearance of national borders.

Companies have realised that sustainability constitutes a means of differentiation, which is crucial for increasing productivity and competitiveness. The adoption of proactive sustainability management has direct and positive repercussions on business' competitiveness [1].

The concept of Corporate Social Responsibility (CSR) and the appearance of guidelines and agreements to standardise the design and implementation of reports on an organisation's environmental, social, and economic performance are good examples of the concern for incorporating an environmental perspective in business management. Several proposals in this sense, such as the “Global Report Initiative” (GRI) have gained recognition worldwide [2,3]. However, even if these initiatives constitute important achievements, its use is left up to organisations, as well as the way in which the chosen ones are applied. This is due to the lack of strict recommendations in this sense.

This reflects a highly important issue: the measure of an organisation's environmental performance. Therefore, different standards usually suggest a list of specific indicators, which can sometimes offer contradictory results. This poses difficulties in diagnosing and reporting results.

Authors such as Holland [4] have pointed out the non-existence of instruments that can synthesise organisations' environmental situation using a holistic approach that can be used for decision-making and communication with shareholders, stakeholders, and society in general.

In this context, several papers [5-11] deal with the possibility of applying EF analysis to companies and their products, contributing ideas or developing different methodologies on measuring corporate ecological footprint (CEF).

The EF is an indicator that assesses the demand for biocapacity by inhabitants of a geographical area to maintain their consumption of resources and generation of wastes using existing technology [12]. Comparing the EF of a given territory with its available biologically productive space (BPS) enables the determination of the extent to which its carrying capacity is exceeded. This indicator dates back to the early 1990s [13,14], and has undergone different changes that solved certain initial deficiencies [15-19].

We are dealing with a versatile tool that is capable of being applied to contexts other than populations, such as organisations, products, and different kinds of activities [14]. Chamber and Lewis and Holland [4,5] report some of the contributions of this indicator towards the achievement of sustainability by firms and organisations. First, this single index synthesizes different environmental impacts and allows an evaluation of the success or the failure of the measures adopted. Second, its calculation methodology is relatively simple. Third, this indicator is expressed in easily understandable units, making decision-making and internal and external reporting manageable. Fourth, the information needed is based on data available in company records.

Some doubts could be cast on the sense of using an indicator that is expressed in hectares of productive space, a unit that is appropriate for countries or regions, but maybe less related to 
corporations. However, the different types of land distinguished by EF also provide information relevant for companies, expressing in a common - and therefore, agreeable - unit the influence of issues such as direct and indirect energy consumption, wastes generation, etc. [4,20].

On the other hand, use of the so-called carbon footprint (CFP) is becoming increasingly widespread. $\mathrm{CFP}$ is a footprint that measures $\mathrm{CO}_{2}$ or other greenhouse gas emissions. As happens with $\mathrm{EF}$, this indicator can be applied to companies and organisations, with the concepts of corporate carbon footprint (CCFP) being a very attractive indicator at this level, especially when we consider the demands in the framework of the Kyoto Protocol.

Different approaches have been used to estimate CCFP [5,9,21-24]. However, there is still no consensus regarding certain matters that determine its content (e.g., the inclusion of $\mathrm{CO}_{2}$ or other gas emissions), scope (only direct emissions or also indirect emissions, being embodied in the purchase of goods and services that need energy in their production), and methodology (classical life-cycle analysis, input-output techniques, etc.). In this paper, we offer a methodological alternative for CCFP, the "method composed of financial accounts" (MC3), which is described in Section 2. Next, we apply MC3 to a wine-producing firm, which enables us to verify the practical utility of the selected method (Section 3). Finally, we discuss the main conclusions obtained (Section 4).

\section{A Methodological Proposal for CCFP Calculation: the Method Composed of Financial Accounts (MC3)}

\subsection{The MC3 Foundations}

The calculation method used, MC3, has been developed by Doménech [9,20]. Doménech starts from the need to make a method that enables the estimation of companies' and organisations' CEF,

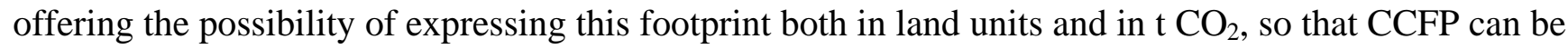
calculated.

The origin of MC3 can be found in the concept of household footprint [25]. In this way, based on the matrix of consumptions versus land present in the spreadsheet for the calculation of households' footprint by Wackernagel [25], Doménech [9] prepares a similar matrix, which contains the consumptions of the main categories of products needed by a company, and also includes sections for the wastes generated and the use of land. These consumptions/wastes will be transformed into land units and $\mathrm{CO}_{2}$.

MC3 was first applied to the Gijón Port Authority [9]. Later on, it was tested and improved by the Working Group on Corporate Ecological Footprint Enhancement, coordinated by Doménech himself, in which five Spanish universities took part. For a year and a half, this method has been applied to firms belonging to different economic sectors [26,31]. This application period proved this method is robust and useful in providing information relevant to improve companies' and organisations' environmental performance in any economic sector.

The CCFP obtained with the current MC3 version includes direct and indirect $\mathrm{CO}_{2}$ emissions, the latter being considered as those generated in the production/provision of goods and services obtained. A second version of this method is currently under development, which will incorporate emissions from the rest of the greenhouse gases included in the Kyoto Protocol, by using the GWP coefficients with a time horizon of 100 years prepared in [32]. These coefficients relate each gas-warming potential 
with $\mathrm{CO}_{2}$-warming potential, which makes the needed conversion possible. For example, a factor 23 means that the contribution by gas unit is 23 times higher than that from $\mathrm{CO}_{2}$.

Hence, this indicator will be expressed in $\mathrm{CO}_{2}$ equivalent tons. Furthermore, emissions derived from the use of land capable of sequestering $\mathrm{CO}_{2}$ in the same way as forest (pastures, croplands, etc.) will also be incorporated in the CCFP. Nonetheless, this paper describes and applies the initial version of the method. The information necessary to estimate CCFP using MC3 is mainly obtained from accounting documents such as the balance sheet and the income statement. Hence, the denomination “method composed of financial accounts" (MC3).

However, further information from other company departments with specific data about certain sections (waste generation, use of land by the organisation's facilities, among others) may also be necessary. The footprint is calculated in a spreadsheet, which is used not only to estimate CCFP, but also to determine CEF. This spreadsheet works as the land-use matrix used for the calculation of countries' EF. Besides showing results, this spreadsheet also makes the estimation of both indicators possible.

\section{Corporate Land-Use Matrix}

The rows of this matrix show the footprint of each category of product/service consumed. The columns present, among other elements, different land-use categories, into which the footprint is divided (see Table 1).

Columns are divided into six groups. The first one (column 1) corresponds to the description of the different categories of consumable products. These are classified into four major categories: energy consumption, which is subdivided into six subgroups (electricity, fuels, materials, construction materials, services, and waste products ), use of land, agricultural resources, fishing resources, and forest resources. One can include as many products as desired within each group.

The second group (columns 2-6) shows each consumption of product, expressed in specific units. The units in the first column of the group are related to product's characteristics (electricity consumption is expressed in $\mathrm{kwh}$, water in $\mathrm{m}^{3} \ldots$.. The second column indicates the value of consumptions in monetary units, while the third shows consumptions in tons. The fifth column reveals energy corresponding to each consumption expressed in gigajoules (GJ), which is obtained by multiplying tons of product by the quantity of energy used by ton in its production $(\mathrm{GJ} / \mathrm{t})$. The result is called energy intensity, indicated in the fourth column.

The third group of columns (columns 7 and 8) show each good's productivity, in a way that one column indicates natural productivity, expressed in tons per hectare, while another presents energy productivity, expressed in GJ per hectare.

The fourth group is composed of six columns (9-14) showing the distribution of the footprint among different categories of land. These are the same as that used for the countries' EF (fossil energy, cropland, pastures, forests, built-up land, and sea).

There is another group (columns 15 and 16), which collects the total ecological footprint (i.e. occupied land) and counterfootprint, that is, available land. The counterfootprint concept will be described in subsequent sections. 
Table 1. Structure of the spreadsheet showing the CEF/CCFP matrix of consumptions versus BPS.

\begin{tabular}{|c|c|c|c|c|c|c|c|c|c|c|c|c|c|c|c|}
\hline \multirow[b]{2}{*}{ PRODUCT CATEGORY } & \multicolumn{5}{|c|}{ ANNUAL CONSUMPTION } & \multicolumn{2}{|c|}{ PRODUCTIVITY } & \multicolumn{8}{|c|}{ FOOTPRINT BY BPS TYPE } \\
\hline & $\begin{array}{l}\text { Consumption } \\
\text { units } \\
\text { [unit/year] }\end{array}$ & $\begin{array}{c}\text { Euros } \\
\text { without } \\
\text { VAT } \\
\text { [Euro/year] }\end{array}$ & $\begin{array}{c}\text { Tons } \\
\text { [t/year] }\end{array}$ & $\begin{array}{c}\text { Energy } \\
\text { intensity } \\
{[\mathrm{GJ} / \mathrm{t}]}\end{array}$ & $\begin{array}{c}\text { GJ } \\
{[\text { GJ/year] }}\end{array}$ & $\begin{array}{c}\text { Natural } \\
\text { [t/ha/year] }\end{array}$ & $\begin{array}{c}\text { Energy } \\
{[G J / \text { ha/year] }}\end{array}$ & $\begin{array}{c}\text { Fossil } \\
\text { energy } \\
{[\mathrm{Ha} * \mathrm{EF}]}\end{array}$ & $\begin{array}{c}\text { Cultivable } \\
\text { land } \\
{[\mathrm{Ha} * \mathrm{EF}]}\end{array}$ & $\begin{array}{l}\text { Pastures } \\
{[\mathrm{Ha} * \mathrm{EF}]}\end{array}$ & $\begin{array}{l}\text { Forests } \\
{[\mathrm{Ha} * \mathrm{EF}]}\end{array}$ & $\begin{array}{c}\text { Built-up } \\
\text { land } \\
{[\mathrm{Ha} * \mathrm{EF}]}\end{array}$ & $\begin{array}{c}\text { Sea } \\
{[\mathrm{Ha} * \mathrm{EF}]}\end{array}$ & $\begin{array}{l}\text { TOTAL } \\
\text { CEF } \\
{[\mathrm{Ha} * \mathrm{EF}]}\end{array}$ & $\begin{array}{c}\text { COUNTERFOOTPRINT } \\
{\left[\mathrm{Ha}^{*} \mathrm{EF} * \mathrm{FR}\right]}\end{array}$ \\
\hline 1. ENERGY & & & & & & & & & & & & & & & \\
\hline 1.1 Electricity & & & & & & & & & & & & & & & \\
\hline 1.2 Fuels & & & & & & & & & & & & & & & \\
\hline 1.3 Materials & & & & & & & & & & & & & & & \\
\hline 1.4 Construction materials & & & & & & & & & & & & & & & \\
\hline 1.5 Services & & & & & & & & & & & & & & & \\
\hline 1.6 Wastes & & & & & & & & & & & & & & & \\
\hline 2. LAND USE & & & & & & & & & & & & & & & \\
\hline $\begin{array}{l}\text { 3. FISHING AND } \\
\text { AGRICULTURAL } \\
\text { RESOURCES }\end{array}$ & & & & & & & & & & & & & & & \\
\hline 4. FOREST RESOURCES & & & & & & & & & & & & & & & \\
\hline
\end{tabular}

t: tonnes; EF: Equivalence factor 


\section{CCFP Calculation}

As discussed earlier, the methodology developed by Doménech is thought to calculate both CCFP and CEF. In this section, we describe the calculation processes of both indicators, stressing the peculiarities of CCFP calculation.

The design of this calculation method starts from the EF philosophy. Nevertheless, there are important differences between an organisation and a population, which reflects in the development of a specific calculation method to study the firms' footprint.

Many of the goods consumed by a company do not come directly from any BPS. Companies purchase machinery and computers, consume electricity, contract services etc., and the ecological footprint of all these consumptions cannot be calculated by dividing the consumption by the productivity of the productive space, from which these goods come, because they are not biotic and therefore do not have any direct origin.

As a consequence, a problem arises, because many goods and services cannot be included in CEF in the usual way. In this case, the method philosophy is similar to that adopted in the study for territories' footprint, since in addition to direct energy consumption, we show the impact of the energy used in the production of goods and services consumed by the organisation studied. These consumptions are precisely those originating from most CCFP.

In the case of territories, the total energy consumption by the inhabitants of a country or region under study is taken into account, making an additional adjustment depending on its goods imports or exports. Since this is not possible with firms, Doménech uses energy intensity factors, which indicate the energy consumed in the production of each product category, expressed in gigajoules per ton. These energy intensity factors would be of the same type as those used in the calculation of countries' footprints to determine the quantity of energy incorporated to commercial flows.

Therefore, the fourth and fifth columns of the second group in the spreadsheet make sense, since we obtain the total energy incorporated in the production of each product multiplied by consumption, which is expressed in tons, by energy intensity $(\mathrm{GJ} / \mathrm{t})$. In the case of depreciable goods, CEF collects its depreciation quota each year, avoiding high fluctuations in the periods when fixed assets are acquired.

Firms' information on some consumption is hardly expressed in tons, while it is normally available in money expenditure or in some cases (fuels, electricity) other physical units, such as litres, kwh, etc. In the first case, the conversion into tons can be made by considering the specific product average prices in the period under study (for example, euros/kg). Another option is to use foreign trade statistics, which offer information about imports and exports of the different tariff chapters expressed in monetary units and tons, thus enabling one to obtain a monetary unit/ton factor. In the second case, the transformation is made considering the item specific weight. In the case of electricity, we consider the quantity of fuel used to obtain one kwh.

Energy intensity factors comprise the amount of energy used in the production of every product included in the corporate land-use matrix (e.g. fertilisers, industrial machinery, etc.), considering an average life cycle. They are obtained from Wackernagel [25,33] and other researchers' studies [34,35].

Regarding biotic or natural resources, whose consumption can be transformed into land in the normal way [14], CEF also includes the energy incorporated in their production, which is calculated 
along with the rest of the goods by applying an energy intensity factor to the consumption of agricultural, fishing, and forest resources.

Energy footprint is also estimated for services contracted by the organisation under study, as well as for the wastes it generates, both aspects being important for the organisations' footprint. In relation to the first, it is assumed that part of the service cost corresponds to energy consumption, and we estimate the weight of this part for each kind of service. After applying this percentage to the service price, we obtain "euros corresponding to the energy consumption" [20]. This value is transformed into tons, considering fuel prices. Afterwards, the corresponding energy intensity is applied, in the same way as when estimating the energy footprint of any other non-biotic resource.

The methodology for waste discharges and emissions is still under development. In the case of wastes, the footprint is based on the calculation of the energy consumed during wastes management. Here, the quantity of energy recovered in recycling processes may be discounted. When doing so, we do not register the possible damaging effects caused by wastes but the energy consumption they generate.

Thus, we obtain the total energy consumed by a given organisation by considering its direct energy consumption of electricity and fuels as well as the part that is indirectly consumed, which is already incorporated in the goods and services used by the firm and in the wastes it generates.

Once this done, the CEF still compares consumption with the quantity of energy that can be assimilated by a hectare of forest according to $\mathrm{CO}_{2}$ emissions; in other words, the energy productivity of each fuel is expressed in GJ/ha. In other words, we estimate how many gig joules of each fuel were needed to emit the $\mathrm{CO}_{2}$ volume that can be absorbed by a hectare annually, applying an absorption rate by hectare and year of $5.21 \mathrm{CO}_{2} \mathrm{t} / \mathrm{ha} /$ year [32]. For instance, an average world forest hectare can absorb e $\mathrm{CO}_{2}$ emissions from a consumption of $71 \mathrm{GJ}$ per year of liquid fuels or $55 \mathrm{GJ}$ of coal [33].

CCFP calculation does not need to resort to these types of factors in this case and total energy

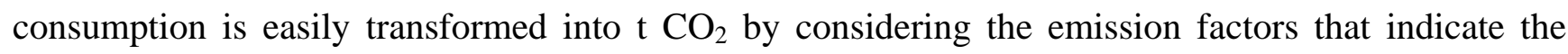
quantity of $\mathrm{CO}_{2}$ emitted by GJ consumed in each type of fuel.

Figure 1. The energy footprint.

\begin{tabular}{|c|c|c|c|c|}
\hline $\begin{array}{c}\text { Consumption } \\
\text { units } \\
\text { (t) }\end{array}$ & $\mathbf{x}$ & $\begin{array}{c}\text { Energy } \\
\text { intensity } \\
(\mathrm{GJ} / \mathrm{t})\end{array}$ & $=$ & $\begin{array}{l}\text { Total } \\
\text { energy } \\
\text { (GJ) }\end{array}$ \\
\hline $\begin{array}{l}\text { Total } \\
\text { energy } \\
\text { (GJ) }\end{array}$ & / & $\mid \begin{array}{c}\text { Energy } \\
\text { productivity } \\
\text { (GJ/ha) }\end{array}$ & $=$ & $\begin{array}{c}\text { Energy } \\
\text { footprint } \\
\text { (ha) }\end{array}$ \\
\hline
\end{tabular}

After this task, we have already obtained most CCFP. To complete it, the calculation method shows the emissions caused by the firm's consumption of forest resources (wood, rubber, paper, etc.). We must remember that an organisation may consume "biotic" resources, such as food and wood, which are directly associated with a type of BPS (croplands, pastures, forests, and sea). In this case, CEF not only includes the energy incorporated in obtaining these goods, estimated as we have specified, but also considers the productive space that is needed to make these consumptions. This land is calculated 
in the normal way found in EF studies, by dividing the consumption of each product, expressed in this case in tons, by the natural productivity of the BPS assigned to each product. Natural productivity collects the amount of every natural resource that humans are able to extract per hectare. Natural productivity data are often obtained from FAO statistics (http://faostat.fao.org/site/339/ default.aspx). For instance, if we consume 10 tons of wood and forest productivity is $1.19 \mathrm{t} / \mathrm{ha}$, the wood footprint assigned to forest land would stand at 8.40 ha, to which the corresponding emission factor should be applied.

Figure 2. The natural footprint.

$\left.\begin{array}{c}\begin{array}{c}\text { Consumption } \\
\text { units } \\
\text { (t) }\end{array} \\
\text { (t/ha) }\end{array}\right]=$\begin{tabular}{c}
$\begin{array}{c}\text { Natural } \\
\text { productivity } \\
\text { (t/ha) }\end{array}$ \\
\hline
\end{tabular}

In addition, consumption from forests contributes to reducing the forest's capacity to absorb $\mathrm{CO}_{2}$. Hence, it is considered that non-absorbed emissions derived from forest products consumed by a firm must be included in its CCFP. In this manner, once we have determined the hectares of forest needed by the organisation under study, these hectares are multiplied by the $5.21 \mathrm{CO}_{2} \mathrm{t} /$ ha absorption rate, to estimate how much $\mathrm{CO}_{2}$ is no longer absorbed.

Finally, CEF applied to organisations shows the use of productive space, both on land and at sea. Thus, the types of land are differentiated (build-up, croplands, pastures), organisations' counterfootprint being also estimated.

The counterfootprint concept can be partially assimilated to the BPS of a country or region. In the traditional ecological footprint analysis, there is a comparison between the land needed to satisfy the needs of a given population, the EF itself, and the productive space available to satisfy these needs. From this comparison, we obtain either a deficit or an ecological reserve, depending on which of the two spaces is larger.

However, the BPS concept makes sense when dealing with territories, but not as much with organisations. All countries use, to a certain extent, part of their land to produce biotic resources. This is why the comparison between available and consumed land is always possible. EF assesses the availability of BPS, and consequently, the fact that a territory population satisfies its needs with products that originate in the territory itself. From the aspect of sustainability condition, a country without productive space can hardly be sustainable, because its inhabitants always need to consume, even just to satisfy their vital needs.

In the case of companies, this assumption is difficult to maintain, since many of them do not need land to produce biotic resources. A car garage or a financial entity will develop their activities without any direct link with this type of resources. This is why the concept of counterfootprint appears. It starts from the positive regard for companies' availability of natural capital, despite the desirable reduction of their footprint by being more efficient and by curbing consumption.

Therefore, investments in this kind of productive space reduce their footprint. In this way, this indicator could encourage the private sector involvement in the preservation of natural spaces (Doménech, 2007), this being considered positive in terms of sustainability. Land devoted to croplands, pastures, forests, gardens, or for instance marine reserves owned by a firm will contribute to 
partially counteract CEF, since all these are considered counterfootprint. To reduce a hectare of footprint, it is necessary to acquire the same quantity of one of these spaces.

When investments are made in wooded land, $\mathrm{CO}_{2}$ emissions and consequently CCFP will also decrease, considering the absorption rate of $5.21 \mathrm{CO}_{2} \mathrm{t} / \mathrm{ha} / \mathrm{year}$. Net $\mathrm{CEF}$ is obtained by subtracting counterfootprint from CEF. In the same way, net CCFP is the result of subtracting the $\mathrm{CO}_{2}$ absorbed by investments in counterfootprint from CCFP.

\subsection{The MC3 and Other Methodological Approaches for the Estimation of CEF and CCFP}

Nowadays, approaches such as BL3 or the "component-based approach" (CBA) estimate CCFP and CFP. Even though the results obtained with these methods and MC3 are similar, there are relevant differences in terms of the calculation method and some assumptions involved in the estimation of the indicator: the CCFP of a given company will be quite different depending on the approach chosen. Some of these differences are linked with issues shown in Table 2.

Table 2. The MC3 and other s methodological approaches.

\begin{tabular}{lccc}
\hline Concept & BL $^{3}$ & CBA & MC3 \\
\hline Calculation method & $\begin{array}{c}\text { Input-output } \\
\text { analysis/LCA }\end{array}$ & $\begin{array}{c}\text { Component- } \\
\text { based } \\
\text { approach/LCA }\end{array}$ & $\begin{array}{c}\text { MC3 is based on } \\
\text { Compound- } \\
\text { Method }\end{array}$ \\
\hline Activities included in CCFP & All the activities & $\begin{array}{c}\text { Relevant } \\
\text { activities }\end{array}$ & All the activities \\
\hline $\begin{array}{l}\text { Transformation of financial information } \\
\text { into mass unit data }\end{array}$ & $\begin{array}{c}\text { No needed. The } \\
\text { method uses } \\
\text { monetary input- } \\
\text { output coefficients }\end{array}$ & $\begin{array}{c}\text { Needed. No } \\
\text { explicit method }\end{array}$ & $\begin{array}{c}\text { Needed. } \\
\text { Explicit method }\end{array}$ \\
\hline Equivalence and yield factors & Yes & No & Yes \\
\hline Is the required software accessible? & No & No & Yes \\
\hline
\end{tabular}

The Input-output analysis is a useful tool to estimate CCFP considering emissions along the supply chain. This method avoids double counting problems and truncation errors, providing comparable footprints [10]. However, it also has some limitations related to sector aggregation, the consumption of imported goods, and errors from the use of country monetary tables, instead of physical unit tables to elaborate input-output coefficients, used to estimate CCFP [37].

CBA estimates the footprint of some relevant components of an organisation resource consumption and waste generation, assessing the CCFP of every component using life-cycle data. Issues such as the completeness of the component list and the reliability of the life-cycle assessment for each component are relevant in terms of the accuracy of the analysis. This approach presents some limitations, given LCAs' boundary problems; the lack of accurate and complete information about products' life-cycles, problems of double-counting in the case of complex chains of production, and the large amount of detailed knowledge necessary for each analysed process [18].

The use of MC3 involves several advantages since:

1. It is a complete method, which collects the footprint from the consumption of all goods and services and wastes generated by a company. 
2. It is based on Wackernagel and Rees' "compound-method”, a solid well-known method for researchers in ecological footprint.

3. It is a technically feasible method. Its calculation does not require extensive expert staff inputs: everybody working with spreadsheets is able to calculate CCFP.

4. It is a transparent method. The spreadsheet and all the data needed for the estimation of CCFP, including energy intensity factors and productivities, are available for researchers at http://www.huellaecologica.com.

5. It is a flexible method. The spreadsheet offers the researchers the possibility of adding/changing the factors employed for the estimation, according to the specific needs of their company.

\section{CCFP Estimation for a Wine Producer in Galicia, Spain}

The company considered for this study, which we will refer to as Gamma, is devoted to the production and marketing of Albariño wine. This is a family-run firm with just two workers, although Gamma hires temporal staff for the grape-harvesting season and related activities, besides relying on other relatives' collaboration. This company's vineyards occupy 2.5 ha, having produced 24,686 kg of grapes in 2006. Moreover, Gamma also buys 19,682 kg of grapes from other producers, which results in a total wine production of 30,000 L.

The information needed to estimate Gamma's CCFP was obtained in two phases. First, the person responsible for supplying data was given information on EF analysis, stressing the utility of this indicator from a corporate perspective.

Subsequently, a tentative survey guide was prepared. The instrument tries to include the main consumption categories needed to estimate its footprint, although new categories were later incorporated, showing specific consumptions that were initially not taken into account. Available information refers to the 2006 accounting period.

\subsection{Results and Discussion}

The following tables and figures show the main results related to Gamma's CCFP. Table 3 shows the company's total $\mathrm{CO}_{2}$ emissions (152.7 $\mathrm{t} \mathrm{CO}$ ). Although vineyards absorb $\mathrm{CO}_{2}$, there are no differences between Gamma's gross and net emissions, because the present MC3 version only considers the counterfootprint from wooded land. MC3 2.0 considers the productive space occupied by vineyards as the counterfootprint.

Table 3. CFP and ratios related to Gamma (2006).

\begin{tabular}{lcc}
\hline Concept & Ud. & Gamma \\
\hline Gross $\mathrm{CO}_{2}$ emissions & $\mathrm{t}$ & 152.7 \\
Net $\mathrm{CO}_{2}$ emissions & $\mathrm{t}$ & 152.7 \\
\hline Sold goods & $\mathrm{t}$ & 27.9 \\
\hline Net $\mathrm{CO}_{2}$ t/goods tons & $\mathrm{t}$ & 5.47 \\
\hline
\end{tabular}

These emissions are related to the quantity of goods sold, $5.47 \mathrm{CO}_{2} \mathrm{t}$ having been determined as the emission per ton of wine produced by Gamma. 
Considering the production of the company, 30,000 litres, the CCFP of a $75 \mathrm{cL}$ bottle of wine is 3,817 $\mathrm{g} \mathrm{CO}_{2}$, nearly five times the footprint shown in previous similar studies [38,39] (i.e. 789 and 835 $\mathrm{g} \mathrm{CO}_{2}$ per $75 \mathrm{cL}$ bottle). We want to remark that MC3 includes $\mathrm{CO}_{2}$ emissions from the production of every good and service consumed by a company, directly or indirectly linked with the production of wine. The footprint of capital goods is estimated allocating the total amount of $\mathrm{CO}_{2}$ generated in their production, considering the duration of their expectable life. Our study also considers emissions from the building process of the company's warehouse, as well as other goods not included in previously mentioned studies. High energy intensities for chemicals and glass by-products also contribute to increase Gamma's CCFP.

The potential usefulness of these results are related to a) the possibility of comparing them with CCFP from other companies within the same sector; b) the analysis of Gamma's CCFP evolution along the time; c) the use of this information to estimate the footprint of the wine produced and marketed by Gamma from a perspective that not only considers the CCFP of the firm itself, but also that of its supplier chain. In this way, this indicator could be used in the preparation of an ecolabel, offering information that consumers might consider when deciding on substitute products.

MC3 allows advancing in the CCFP origin. A first classification distinguishes among emissions from consumption (either direct or indirect), from energy (133.7 $\mathrm{t} \mathrm{CO}_{2}$ ), and those caused by forest resources consumption (18.95 t CO 2 ) (Table 4).

Table 4. Gamma's CCFP: types of footprint.

\begin{tabular}{l|cc}
\hline \multicolumn{1}{c|}{ Type of Footprint } & $\boldsymbol{t} \boldsymbol{C O}_{2}$ & \% \\
\hline Fossil energy & 133.7 & 87.6 \\
Forest & 18.95 & 12.4 \\
\hline Total & $\mathbf{1 5 2 . 7}$ & $\mathbf{1 0 0}$ \\
\hline
\end{tabular}

Likewise, we can determine what consumptions hide from each one of these categories. In terms of energy, Figure 3 shows the distribution of $\mathrm{CO}_{2}$ tons generated by the Gamma's direct and indirect energy consumption. We have observed that in $67 \%$ of these emissions, $88.6 \mathrm{t} \mathrm{CO}_{2}$, comes from the energy incorporated in the production of non-depreciable materials consumed. Second, the consumption of agricultural resources and specifically of grapes - this firm's raw material - generates $14.4 \mathrm{CO}_{2}$ tons or $12 \%$ of emissions. 
Figure 3. Gamma’s CCFP: energy consumption.

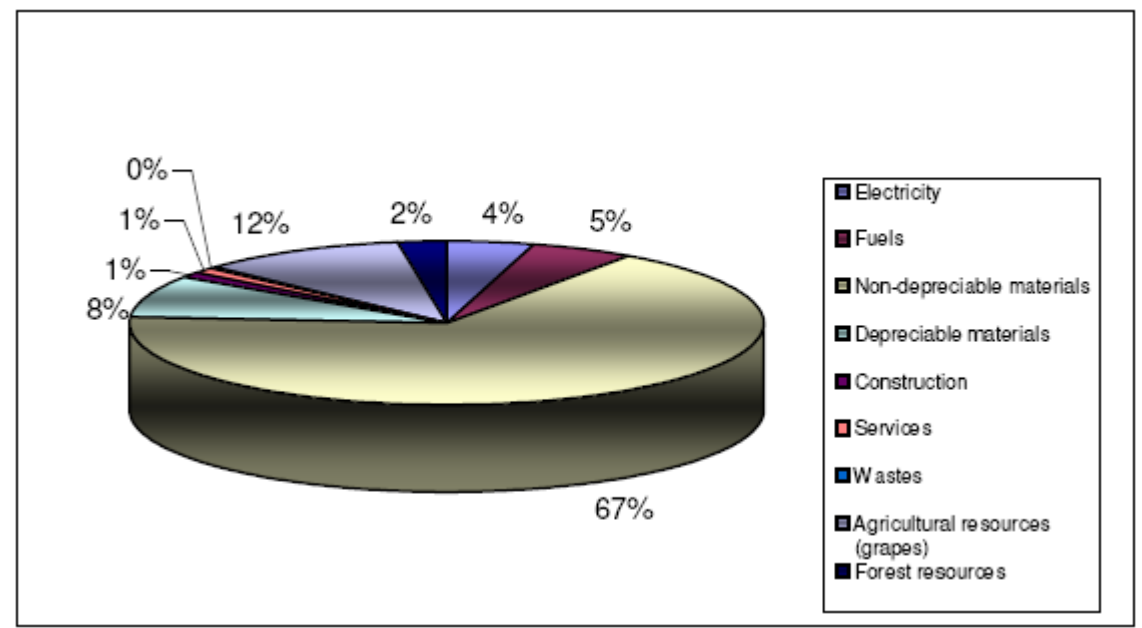

In this case, we are dealing with a product with low energy intensity, $10 \mathrm{GJ} / \mathrm{t}$, but from whose Gamma acquires an important volume $(19.7 \mathrm{t})$. The third $\mathrm{CO}_{2}$ generator from fossil energy consumption is depreciable material, which generates $11.3 \mathrm{t} \mathrm{CO}_{2}, 8 \%$ of the total. It is remarkable that depreciable and non-depreciable materials are separated. In the case of the former, consumption is associated with the depreciation quota of the specific year. As for the latter, the real consumption of goods is shown.

Thus, we notice that over $85 \%$ of the $\mathrm{CO}_{2}$ associated with energy consumption as well as almost $75 \%$ of the total CCFP are generated by just three consumption categories. Other consumptions such as fuels $\left(7.2 \mathrm{t} \mathrm{CO}_{2}\right)$ or electricity $\left(5.9 \mathrm{t} \mathrm{CO}_{2}\right)$, with a priori more visible emissions, are less important in this company.

Given the importance of the emissions from materials, we consider it appropriate to advance further, indicating which are those with the highest contributions to Gamma's CCFP. In terms of agricultural resources, total emissions are associated with a single product (grapes); hence, more advances are not necessary.

Figure 4. CCFP from non-depreciable materials $\left(\mathrm{t} \mathrm{CO}_{2}\right)$.

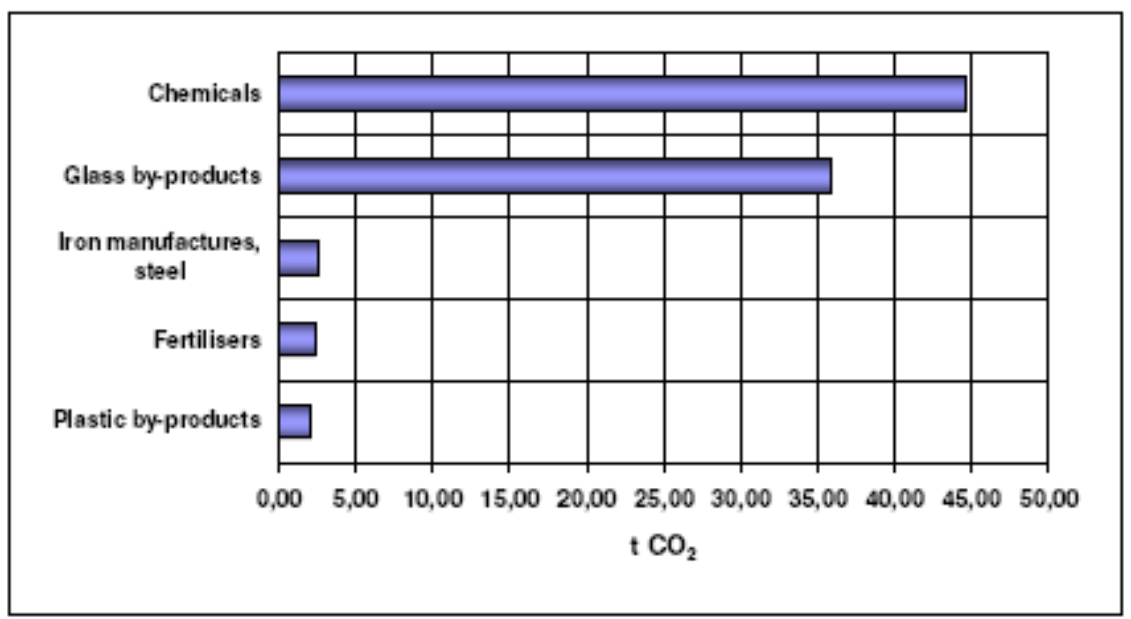


Figure 4 shows the five non-depreciable materials with the highest CCFP. Chemicals $\left(44.57 \mathrm{t} \mathrm{CO}_{2}\right)$ stand out, which include sulfates used by Gamma, and glass byproducts $\left(35.70 \mathrm{t} \mathrm{CO}_{2}\right)$, result of consumption of bottles to bottle the firm's production. Emissions from other materials, such as iron and steel manufactures (mainly non-depreciable machinery), fertilisers, and plastic-derived products (boxes for grape-harvesting and synthetic furniture) rank next, although none of them reaches 3 t $\mathrm{CO}_{2}$.

Figure 5. CCFP from depreciable materials $\left(\mathrm{t} \mathrm{CO}_{2}\right)$.

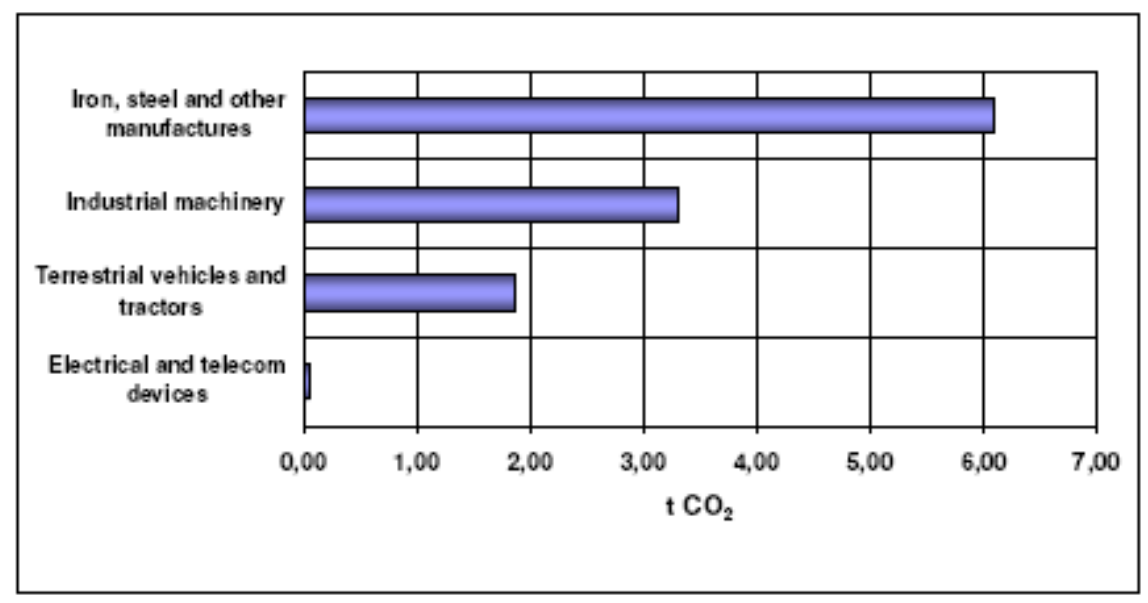

With regard to depreciable materials (Figure 5), their CCFP is considerably lower. In this respect, the $6.10 \mathrm{CO}_{2} \mathrm{t}$ emission generated by the consumption of iron and steel manufactures is outstanding, which are related to the freezing tanks where wine is stored. Emissions generated from the production of specialised wine-making machinery (mainly bottling line, corking machines, and conveyor belts) reach $3.31 \mathrm{CO}_{2}$ tons, while emissions associated with other consumption concepts such as automobile vehicles and electrical devices are notably lower.

Figure 6. Gamma's CCFP: Consumption of forestry resources $\left(\mathrm{t}^{\mathrm{CO}_{2}}\right)$.

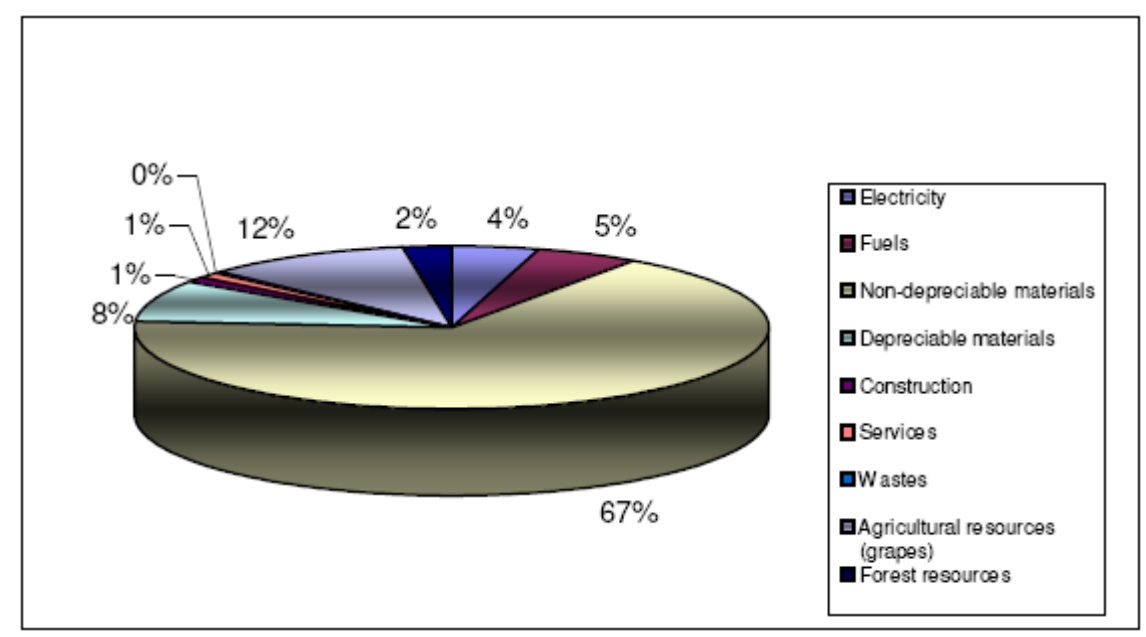

Emissions associated with forestry resources consumption (Figure 6) represent 12.4\% of CCFP, reaching $18.95 \mathrm{t} \mathrm{CO}_{2}$. In this case, $63 \%$ of emissions $\left(11.77 \mathrm{t} \mathrm{CO}_{2}\right)$ comes from the consumption of cork products and their manufactures, in Gamma this being related to the purchase of cork for the 
40,667 bottles needed for its 2006 production. Packing these bottles implies an important consumption of boxes and cardboard cases, making emissions associated with paper and cardboard consumption reach $5.9 \mathrm{t} \mathrm{CO}_{2}$. Wood consumption, in Gamma's furniture and in the building of the firm's premises, does not reach $1 \mathrm{t} \mathrm{CO}_{2}$.

\section{Conclusions}

The search for sustainability by organisations and companies is driven by the need to attain global sustainable development as well as a management tool to enhance a firm's value. Tools for assessing corporate environmental performance is a requisite for firms committed to the environment and to a view of business management beyond the traditional models.

The method composed of financial accounts (MC3) is presented as an alternative when the assessment of the firms' or organisations' sustainability based on their CCFP is included. This is compatible with well-known information standards, such as the "Sustainability Guidelines" of the Global Reporting Initiative (GRI). Moreover, this can be used to estimate a product's footprint, by adding the footprint corresponding to all firms, through which a given product circulates along its life cycle.

In this paper, we have applied MC3 to a company that we called Gamma, focusing in the calculation of its CCFP. We have verified that the information obtained is relevant for the design of measures targeted at the reduction of its $\mathrm{CO}_{2}$ emissions. Results obtained indicate the activities generating the highest CCFP, which helps in determining the contribution of each consumption. Since both direct and indirect emissions are included, some activities appear whose impacts are not always easily noticed, a circumstance that increases the intervention possibilities.

Gamma should try to manage its materials in a more efficient way, reducing their consumption. This task may prove difficult on the short term for depreciable goods, since they are the firm's production means, and acquired to last for years. As for non-depreciable goods, the intervention margin is wider. In some cases (glass bottles or corks), it is difficult to reduce the number of units consumed without substantially affecting the firm's economic profitability. Despite this, a possible solution would be to try to purchase products with a lower weight per unit. In products such as fertilisers, for instance, the optimisation of consumption will contribute toward reducing Gamma's CCFP.

\section{Acknowledgements}

We would like to acknowledge the collaboration of Ana Elisa Rodríguez Carril, Gamma representative, and Anxo Estévez Carril, whose effort made this study possible.

\section{Research Grants}

This study was made possible thanks to the financial support of the research project "Ecological Footprint for IMAPS (Integrated Management of risks and Environment in Port Cities), leaded by the Port of Gijón. 


\section{References}

1. An introduction to corporate environmental management: striving for sustainability, 1st ed.; Schaltegger, S., Burritt, R., Petersen, H., Eds.; Greenleaf Publishing: Sheffield, UK, 2003; pp. 1-384.

2. GRI (Global Reporting Initiative). Sustainability Reporting Guidelines; Available online: http://www.aeca.es/comisiones/rsc/documentos_fundamentales_rsc/gri/guidelines/gri_guidelines_ 2002.pdf (accessed October 23, 2006).

3. GRI (Global Reporting Initiative). Sustainability Reporting Guidelines. Available online: http://www.globalreporting.org/NR/rdonlyres/ED9E9B36-AB54-4DE1-BFF2-5F735235CA44/0/ G3_GuidelinesENU.pdf (accessed November 23, 2008).

4. Holland, L. Can the Principle of the Ecological Footprint be Applied to Measure the Environmental Sustainability of Business? Corp. Soc. Responsibility Environ. Manage. 2003, 10, 224-232.

5. Chambers, N.; Lewis, K. Ecological Footprint Análisis: Towards a Sustainability Indicador for Business. ACCA Research Report No. 65, Oxford, UK, 2001.

6. Lenzen, M.; Lundie, S.; Bransgrove, G.; Charet, L.; Sack, F. Assessing the Ecological Footprint of a Large Metropolitan Water Supplier: Lessons for Water Management and Planning towards Sustainability. J. Environ. Plan. Manage. 2003, 46, 113-141.

7. Lenzen, M.; Foran, B.; Dey, C. Sustainability Accounting for Business - A new International Software Based on Input-Output Tables. Paper presented at the Intermediate Input-Output Meeting Conference, Sendai, Japan, 26-28, July, 2006.

8. Wiedmann, T.; Lenzen, M. Sharing Responsibility along Supply Chains - A New Life-Cycle Approach and Software Tool for Triple-Bottom-Line Accounting. Working paper presented at the Corporate Responsibility Research Conference, Trinity College Dublin, Ireland, 4-5, September, 2006.

9. Doménech, J.L. La huella ecológica empresarial: el caso del puerto de Gijón. Working paper preseted at the VIIth Nacional conference of environment, Madrid, Spain, 22-26, November, 2004.

10. Wiedmann, T.; Barret, J.; Lenzen, M. Companies on the Scale: Comparing and Benchmarking the Footprints of Businesses. Working paper presented at the International Ecological Footprint Conference, Cardiff University, Cardiff, Wales, 8-10, May, 2007.

11. Murray, J.; Dey, C. Assessing the Impacts of a Loaf of Bread; ISA Research Report 04-07: Sydney, Australia, 2007; pp. 1-43.

12. Wackernagel, M.; Monfreda, Ch.; Moran, D.; Wermer, P.; Goldfinger, S.; Deumling, D. Ecological footprint time series of Austria, the Philippines, and South Korea for 1961-1999: comparing the conventional approach to an actual land area' approach. Land Use Policy 2005, 21, 261-269.

13. Rees, W.E. Ecological Footprints and Appropriated Carrying Capacity: What Urban Economists Leaves Out. Environ. Urban. 1992, 4, 121-130.

14. Wackernagel, M.; Rees, W.E. Our Ecological Footprint: Reducing Human Impact on the Earth, 2nd ed.; New Society Publishers: Philadelphia, USA, 1996; pp. 1-160. 
15. Wackernagel, M. The Ecological Footprint of Santiago de Chile. Local Environ. 1998, 3, 7-25.

16. Wackernagel, M.; Silverstein, J. Big Things First: Focusing on the Scale Imperative with the Ecological Footprint. Ecol. Econ. 2000, 32, 391-394.

17. Wackernagel, M.; Schulz, N.; Deumling, D.; Callejas Linares, A.; Jenkins, M.; Kapos, V.; Monfreda, C.; Loh, J.; Myers, N.; Norgaard, R.; Randers, J. Tracking the Ecological Overshoot of the Human Economy. Proc. Nat. Acad. Sci. 2002, 99, 9266-9271.

18. Monfreda, Ch.; Wackernagel, M.; Deumling, D. Establishing National Natural Capital Accounts Based on Detailed Ecological Footprint and Biological Capacity Assessment. Land Use Policy 2004, 21, 231-246.

19. Kitzes, J.; Peller, A.; Goldfinger, S.; Wackernagel. M. Currents Methods for Calculating National Ecological Footprint Accounts. Sci. Environ. \& Sustain. Soc. 2007, 41, 1-9.

20. Doménech, J.L. Huella ecológica y desarrollo sostenible, 1st ed.; AENOR Ediciones: Madrid, Spain, 2007; pp. 1-398.

21. GFN (Global Footprint Network). Ecological footprint and biocapacity. Technical notes: 2006 ed., Oakland, CA, USA, 2006.

22. Wiedmann, T.; Lenzen, M. Unravelling the impacts of supply chains. A new Triple-Bottom-Line Accounting Approach; ISA UK Research Report 07-02: Durham, UK, 2007; pp. 1-26.

23. Wiedmann, T.; Minx, J. A definition of carbon footprint; ISA UK Research Report 07-01: Durham, UK, 2007; pp. 1-11.

24. BSI (Bristish Standards Institute). Specification for the assessment of the life cycle greenhouse emissions of goods and services. Available online: http://www.bsigroup.com/en/Standards-andPublications/Industry-Sectors/Energy/PAS-2050/ (accessed November 10, 2008).

25. Wackernagel, M.; Dholakia, R.; Deumling, D.; Richardson, D. Assess your Household's Ecological Footprint 2.0. Available online: http://greatchange.org/ng-footprintef_household_evaluation.xls (accessed November 1, 2005).

26. Álvarez Díaz, P.D.; Doménech Quesada, J.L.; Perales Vargas-Machuca, J.A. Huella ecológica energética corporativa: Un indicador de la sostenibilidad empresarial. Revista OIDLES 2008, 1, $1-25$.

27. Carballo Penela, A.; García-Negro, M.C.; Doménech Quesada, J.L.; Villasante, C.S.; Rodríguez Rodríguez, G.; García Arenales, M. A pegada ecolóxica corporativa: concepto e aplicación a dúas empresas pesqueiras de Galicia. Revista Galega de Economía 2008, 17, 149-176.

28. Caselles Moncho, A.; Carrasco Esteve, M.; Martínez Gascón, A.; Coll Ribera, S.; Doménech, J.L.; González Arenales, M. La huella ecológica corporativa de los materiales: aplicación al sector comercial. Revista OIDLES 2008, 1, 1-24.

29. Coto Millán, P.; Mateo Mantecón, I.; Doménech, J.L.; Quesada, Y.; González-Arenales, M. La Huella Ecológica de las Autoridades Portuarias y los Servicios. Revista OIDLES 2008, 1, 1-27.

30. Doménech, J.L.; González-Arenales, M. La huella ecológica de las empresas: 4 años de seguimiento en el Puerto de Gijón. Revista OIDLES 2008, 1, 1-23.

31. Marañon, E.; Iregui, G.; Doménech, J.L.; Fernández-Nava, Y.; González-Arenales, M. Propuesta de índices de conversión para la obtención de la huella de los residuos y los vertidos. Revista OIDLES 2008, 1, 1-22. 
32. IPCC (International Panel on Climate Change). Greenhouse Gas Inventory: workbook. Revised 1996 IPCC Guidelines, Vol 2. Available online: http://www.ipcc-nggip.iges.or.jp/public/gl/ nrgspan.html (accessed October 6, 2008).

33. Wackernagel, M. The Ecological Footprint of Italia: Calculation Sheet. Available online: http://www.iclei.org/ICLEI/ef-ita.xls (accessed November 20, 2005).

34. Ibañez Etxeburúa, N. La huella ecológica de Donostia-San Sebastián. Available online: http://www.agenda21donostia.com/cas/corporativa/docs/huellaeco.pdf (accessed November 1, 2005).

35. Mayor Farguell, X.; Quintana Gozalo, V.; Belmonte Zamora, R. Aproximación a la huella ecológica de Cataluña. Available online: http://www.catsostenible.org/pdf/DdR_7_Huella_ Ecologica.pdf (accessed Novomber 6, 2006).

36. Álvarez Díaz, P.D.; Doménech Quesada, J.L.; Perales Vargas-Machuca, J.A. Huella ecológica energética corporativa: Un indicador de la sostenibilidad empresarial. Revista OIDLES 2008, 1, 1-25.

37. Suh, S.; Lenzen, M.; Treloar, G.J.; Hondo, H.; Horvath, A.; Huppes, G.; Jolliet, O.; Klann, U.; Krewitt, W.; Moriguchi, Y.; Munksgaard, J.; Norris, G. System Boundary Selection in Life-cycle Inventories. Environ. Sci. Technol. 2004, 38, 657-664.

38. Aranda, A.; Zabalza, I.; Scarpellini, S. Economic and Environmental Analysis of the Wine Bottle Production in Spain by means of Life Cycle Assessment. International Journal of Agricultural Resources, Governance and Ecology (Special Issue on Life Cycle Assessment in the Terciary Sector) 2005, 4, 178-191.

39. Fullana, P.; Gazulla, C.; Clavijo, M.J.; Puerta, M.; Tubilleja, M. Análisis del ciclo de vida del vino de crianza D.O.C. Rioja. Dirección General de Calidad Ambiental, Consejería de Turismo, Medio Ambiente y Política Territorial del Gobierno de La Rioja, 2005.

(C) 2009 by the authors; licensee Molecular Diversity Preservation International, Basel, Switzerland. This article is an open-access article distributed under the terms and conditions of the Creative Commons Attribution license (http://creativecommons.org/licenses/by/3.0/). 